\title{
PENDIDIKAN KARAKTER BAGI ANAK USIA DINI MELALUI BUKU CERITA BERGAMBAR
}

\author{
Ashiong Parhehean Munthe \\ Fakultas Ilmu Pendidikan, Universitas Pelita Harapan \\ ashiong.munthe@uph.edu \\ Dellya Halim \\ Sekolah St. Theresia, Jakarta, \\ Mahasiswa Magister Pendidikan Universitas Pelita Harapan \\ dellyahalim02@gmail.com
}

\begin{abstract}
The picture-story book that emphasize character values in accordance with the vision and mission of Santa Theresia Jakarta Kindergarten is very urgent to develop, because at school, character education books are not available with the value of servite et amate. This was revealed by a teacher through an interview. Based on observations, it was also found that there was indeed no character education book that was in accordance with the school's vision and mission. Character education or moral education in the present context, really needs to be taught and developed, so that children's morals can be formed early. Picture-story book is a book in which there are stories, characters, grooves, backgrounds, themes that are expressed in the form of writings and images that become one unit. Through reading books, it is easier for children to understand the contents and practical examples to apply the character values that they want to teach. This study uses descriptive qualitative methods. The qualitative descriptive is an attempt to explain facts, data, or objects qualitatively in the form of language or discourse by interpreting them appropriately and systematically. Data collection techniques used were interview and observations. This research was conducted at the Santa Theresia Jakarta Kindergarten. The results of the study indicated that picture-story books that were in accordance with the values of servite et amate needed to be created and developed, in order to help children in early childhood easily understood examples of character actions that must be performed. Therefore, schools need to facilitate and fully support, so that kindergarten teachers are given space and opportunities to develop pictorial story books. The content of the story, character, plot, language, selection of diction, choosing the color of the image must be relevant for early childhood.
\end{abstract}

Keywords: early childhood, picture story books, urgency of character education

\section{PENDAHULUAN}

Bagi anak usia dini mendengar cerita adalah kegiatan yang menyenangkan, karena pada umumnya setiap anak menyukai cerita (Soehendro, 2011). Menyampaikan kisah atau cerita bisa dilakukan untuk menyampaikan nilai-nilai penting untuk diketahui dan dilakukan oleh anak. Namun, akan lebih menarik, jika kegiatan bercerita tersebut dilakukan dengan menggunakan visualisasi gambar. Dengan adanya gambar akan mempermudah anak untuk membayangkan isi dan alur cerita yang disampaikan. Kehadiran buku cerita bergambar menjadi sesuatu yang umum dan lumrah bagi anak. Dipakai juga sebagai salah satu sumber pembelajaran. Menarik sebagai sumber pembelajaran, karena cerita dapat divisualisasikan dengan gambar dan warna-warna yang menarik sesuai dengan alur dan latar cerita. 
Sebutan Anak Usia Dini merupakan rentang usia anak nol (0) hingga lima (5) tahun. Pada usia ini disebut juga sebagai golden age atau masa keemasan. Pada masa keemasan tersebut, anak sudah mulai sensitif terhadap berbagai stimulus dan sangat menyukai buku cerita dengan gambar-gambar yang menarik. Usia Dini juga sebagai peletak dasar untuk mengembangkan semua potensi di bidang motorik, sosio emosional, kognitif, bahasa, agama, moral dan mengalami pertumbuhan dan perkembangan yang pesat dalam berbagai aspek lainnya (Hartati, 2005). Menurut Piaget (dalam Berk, 2012) bahwa anak usia dini (dalam rentang 4-5 tahun) berada pada tahap pra operasional konkret. Pada masa usia ini disebut sebagai momen yang paling tepat untuk mengajarkan dan menumbuh kembangkan nilai karakter.

Menurut Suyanto (2005) bahwa anak pada usia dini sedang dalam masa pertumbuhan baik secara fisik maupun secara mental. Pada usia ini, anak juga tidak hanya mengalami perkembangan secara fisik dan motorik saja, tetapi juga mengalami pertumbuhan dan perkembangan secara kepribadian, watak, emosional, intelektual, bahasa, dan moral secara pesat. Pertumbuhan dan perkembangan saraf otak sudah dimulai sejak dalam kandungan hingga pasca kelahiran. Seluruh sel saraf otak akan terus mengalami perkembangan hingga "sempurna" yang diiringi perkembangan fisik dan mental juga.

Pembentukan karakter awal pada usia dini tidak boleh gagal, karena kegagalan tersebut akan berdampak negatif hingga anak beranjak besar hingga dewasa. Oleh karena itu, pendidikan karakter sejak dini harus dilakukan demi generasi masyarakat dan bangsa yang lebih baik. Dengan diberikannya pendidikan karakter sejak usia dini, tentu akan membentuk karakter, agar anak memiliki perilaku yang baik sejak dini. Dengan demikian, anak sudah dilatih agar tidak berprilaku nakal, tidak melanggar aturan, tidak melakukan kekerasan terhadap teman atau perilaku lain yang tidak sesuai dengan ajaran agama maupun moral.

Pendidikan karakter sejak usia dini dilakukan untuk menanamkan dan menumbuhkembangkan kesadaran, pengertian, kemampuan menilai, maupun kemampuan menjawab permasalahan yang dihadapi secara personal maupun kelompok. Untuk selanjutnya, melalui pendidikan karakter tersebut, anak akan mampu mengembangkan budi pekerti yang sesuai moral bangsa dan nilai agama dengan terus menerus. Dengan penanaman budi pekerti dan karakter sejak dini, maka hal ini dapat mencapai cita-cita bangsa dan tujuan nasional, yaitu manusia cerdas dan berakhlak mulia.

Dengan demikian, pendidikan karakter yang dimulai sejak dini sangat dibutuhkan. Baik untuk kepentingan secara institusional sekolah, maupun demi kehidupan berbangsa dan bernegara. Namun, yang terutama adalah bagi siswa itu sendiri secara personal, agar mampu mempersiapkan masa depan yang lebih baik. Oleh karena itu, sekolah perlu merancang secara sistematis pendidikan yang menekankan pada karakter sejak anak usia dini. Pendidikan karakter yang dirancang haruslah sesuai dengan visi dan misi sekolah yang tentunya terkait juga dengan tujuan pendidikan nasional Indonesia. 
Ada beberapa hasil penelitian yang sudah dilakukan terkait dengan pendidikan karakter anak. Nur (2013) mengungkapkan tentang manfaat dari jenis-jenis permainan anak tradisional dalam membangun karakter anak. Prasanti dan Fitriani (2018) mengungkapkan tentang pembentukan Karakter Anak Usia Dini meliputi faktor Keluarga, Sekolah, dan Komunitas. Turan dan Ulutas (2016) melakukan penelitian dengan tujuan untuk menyelidiki pandangan dan implementasi guru prasekolah dalam pendidikan karakter melalui buku cerita bergambar. Dari hasil penelitian Turan dan Ulutas tersebut menunjukkan bahwa penerapan pendidikan karakter sangat penting dan efektif dengan memakai buku cerita bergambar. Buku cerita bergambar bagi guru sangat berguna dan efektif untuk menyampaikan muatan pelajaran pendidikan karakter. Guru, selain memiliki kompetensi untuk mengajarkan nilai-nilai karakter dengan menggunakan buku cerita bergambar, harus menjadi role model atau panutan juga dalam praktik pendidikan karakter. Metode-metode yang dipakai guru untuk pendidikan karakter juga harus kreatif dan aplikatif, misalnya seperti menggunakan metode drama, permainan, tanya jawab dan lain sebagainya. Metode variatif dan kreatif lebih efektif dan disukai oleh anak-anak untuk mengajarkan pendidikan karakter. Berdasarkan hasil penelitian Turan dan Ulutas (2016) tersebut serta pentingnya pendidikan karakter, maka penulis hendak menguraikan peranan buku cerita bergambar serta urgensinya pendidikan karakter bagi anak usia dini.

\section{KAJIAN PUSTAKA}

\section{Buku Cerita Bergambar bagi Anak Usia Dini}

\section{a) Buku Cerita}

Buku cerita adalah cerita yang dituangkan secara tertulis yang berbentuk buku. Buku cerita dipergunakan sebagai sumber belajar untuk menyampaikan pesan-pesan yang terkandung dalam buku cerita. Cerita dapat diartikan sebagai rangkaian peristiwa yang disusun secara lisan maupun tertulis. Ide cerita yang hendak ditulis bisa bersumber dari pengalaman atau kisah nyata atau kisah tidak nyata (imajinasi penulis). Buku cerita pada dasarnya merupakan salah satu buku teks bacaan yang dibuat untuk pembelajaran. Buku cerita juga merupakan sumber yang akrab bagi anak-anak dan disukai oleh orangtua serta guru (Rideout, Vandewater, \& Wartella, 2003).

Cerita yang disajikan dalam buku, khususnya untuk anak usia dini, adalah cerita yang pendek. Menurut Kosasih (2009), cerita yang pendek adalah cerita yang biasanya selesai dibaca sekitar sepuluh menit sampai setengah jam atau dengan kata lain selesai dalam sekali duduk. Kemudian menurut Nurgiyantoro (2013) bahwa buku cerita yang baik untuk anak harus memiliki kriteria sperti isi cerita atau materi yang dimuat mudah dipahami oleh anak, bahasa atau diksi yang dipilih harus yang mudah dipahami dan dibaca anak, serta buku cerita tersebut harus mampu meningkatkan kemampuan berbahasa anak. 
Cerita anak juga memiliki karakteristik unik yang berbeda dari karya sastra pada umumnya. Seperti yang dijelaskan oleh Nodelman (dalam Soelistyarini, 2011) bahwa ada empat karakteristik yang umum ditemui dalam karya sastra anak, yang pertama adalah gaya bahasa yang dipilih sederhana, karena harus disesuaikan dengan usia pembaca. Kedua, paparan cerita harus langsung dan fokus pada aksi, yaitu terkait langsung dengan yang dilakukan oleh tokoh dalam cerita dan akibat dari tindakan tersebut. Ketiga, memberikan informasi visual dengan gambar atau ilustrasi yang berfungsi untuk memberi informasi dan dorongan emosional yang tidak dapat dikomunikasikan hanya melalui teks saja. Karakteristik yang keempat adalah pemilihan tokoh utama dalam cerita dapat berupa binatang atau anak-anak. Namun yang memiliki sifat atau perilaku seperti anak-anak juga, agar pembaca anak dapat mengidentifikasi diri dengan tokoh tersebut.

\section{b) Buku Cerita Bergambar}

Buku cerita bergambar bermanfaat sebagai sarana pembelajaran maupun sebagai sumber belajar yang mudah ditemukan. Buku cerita bergambar juga berupa benda konkret yang dapat diraba dan dilihat anak secara langsung. Buku cerita bergambar berguna untuk menyampaikan cerita dalam bentuk buku dengan rangkaian isi cerita, disertai dengan ilustrasi gambar, yang berfungsi sebagai penghias dan pendukung cerita. Melalui buku cerita bergambar tersebut, pembaca diharapkan dapat lebih mudah memahami pesan dan deskripsi cerita yang hendak disampaikan.

Secara teoretis buku cerita bergambar adalah buku yang isinya ada gambar dan kata-kata, namun gambar dan kata-kata tidak berdiri sendiri-sendiri, melainkan saling bergantung menjadi satu kesatuan cerita (Adipta, Maryaeni, \& Hasanah, 2016). Rothlein \& Meinbach (1995) menjelaskan bahwa pesan yang tertuang dalam buku cerita sama pentingnya antara ilustrasi gambar dan teks. Dapat disimpulkan bahwa buku cerita bergambar adalah buku yang saling terkait antara gambar dengan teks menjadi satu kesatuan yang utuh membentuk sebuah rangkaian cerita.

\section{c) Peran Buku Cerita Bergambar untuk Anak Usia Dini}

Pertumbuhan kognitif anak, menurut Piaget, bergerak mulai dari hal yang konkrit ke hal-hal yang abstrak (Mueller, 2006). Paparan tersebut, jika dikaitkan cara berpikir anak, maka pemahaman anak akan terbantu melalui benda-benda (objek-objek) atau peristiwa-peristiwa yang bisa secara langsung dilihat dan dialami anak. Memanfaatkan buku cerita bergambar dalam pembelajaran akan menolong anak lebih mudah berpikir dari yang konkrit ke abstrak. Dalam buku cerita bergambar, jamak ditemukan hal yang konkrit dalam kehidupan anak, dimasukkan dalam cerita. Melalui buku cerita bergambar juga akan lebih mudah untuk memperkenalkan kosa kata baru yang dibantu dengan ilustrasi gambar. Dengan demikian, anak lebih mudah mengenal bentuk kata dan gambar tersebut secara konkrit. Jikalau cerita tersebut diulang kembali, maka anak akan mampu mengingat secara abstrak di dalam pikiran mereka. 
Buku cerita bergambar memiliki peran yang penting, karena sangat membantu siswa untuk belajar tentang alam, mengenal individu lainnya dan memiliki kaitan dengan pengembangan perasaan (Nurgiyantoro, 2013). Dengan demikian, anak dapat memahami dan menghubungkannya dengan pengalaman pribadinya, menstimulasi imajinasi, memperoleh kesenangan serta keberadaan di tengah masyarakat.

Anak-anak usia sekolah, menurut Hurlock dalam Faizah (2009), sangat menyukai cerita bergambar, karena beberapa alasan berikut ini, yaitu: (1) lewat cerita tersebut anak memperoleh kesempatan untuk memahami masalah secara pribadi maupun secara sosialnya. Hal tersebut, akan membantu anak untuk cerdas dalam menyelesaikan masalah yang dihadapinya; (2) cerita bergambar menuntun anak untuk berimajinasi dan mendorong keingintahuan anak; (3) mudah dibaca dan dipahami anak, karena anak yang kurang mampu membaca, dapat memanfaatkan gambar untuk memahami isi ceritanya meskipun belum bisa membaca; (4) buku cerita bergambar sudah umum dan tidak sulit untuk ditemukan; (5) buku cerita distimulus oleh gambar agar anak tertarik membaca; (6) cerita bisa dibuat berbentuk serial, sehingga mendorong rasa penasaran anak; (7) tokoh dalam cerita sering bertindak atau melakukan sesuatu yang tidak berani dilakukannya sendirian, meskipun mereka ingin melakukannya, hal ini sangat menggembirakan; (8) sosok tokoh yang ada dalam cerita ditampilkan sebagai orang kuat, pemberani, dan berwajah menawan. Hal ini membuat anak tertarik dan ingin mengikuti sang tokoh (idola); (9) tampilan gambar dalam cerita penuh dengan warna dan cukup sederhana agar mempermudah anak memahami cerita.

Dengan karakteristik anak usia dini yang berada pada tahap pra operasional konkret, maka anak masih membutuhkan benda-benda konkret untuk membantu proses berpikir. Anak usia dini juga masih sedang mengembangkan keterampilan berpikir dan bahasanya. Dengan demikian, penggunaan buku cerita bergambar merupakan satu cara yang baik dan tepat untuk menyampaikan materi pengetahuan atau pembelajaran.

\section{Pendidikan Karakter dan urgensinya untuk anak usia dini}

Secara etimologi, kata karakter berasal dari bahasa Yunani "karasso" artinya sebagai 'cetak biru', 'format dasar', 'sidik' seperti dalam sidik jari (Koesoema, 2007). Hal ini dapat diartikan sebagai sesuatu menandai atau dalam bahasa Inggris disebut to mark yang tujuan utamanya adalah mengimplementasikan nilai kebaikan melalui tindakan atau tingkah laku. Pengertian karakter menurut Kementerian Pendidikan Nasional adalah watak, tabiat, akhlak, atau kepribadian seseorang yang terbentuk dari hasil internalisasi berbagai kebajikan (virtues) yang diyakini dan digunakan sebagai landasan untuk cara pandang, berpikir, bersikap, dan bertindak. Kebajikan (virtues) diartikan terdiri atas sejumlah nilai, moral, dan norma, seperti jujur, berani bertindak, dapat dipercaya, dan hormat kepada orang lain (Kementerian Pendidikan Nasional, 2010). 


\section{a) Urgensi Pendidikan Karakter}

Pendidikan terbaik bukan hanya sekedar menekankan pada kecerdasan intelektual semata, namun pendidikan yang menanaman dan menumbuhkan nilai karakter sejak dini, seperti menekankan moral, akhlak mulia dan budi pekerti sangat penting. Pendidikan karater harus dimulai sejak anak masih usia dini, karena pada usia-usia ini merupakan masa pembentukan otak dan karakter seorang anak. Dalam pendidikan karakter, yang ditekankan bukan hanya mengajarkan mana yang benar dan mana yang salah kepada anak. Namun lebih dari pada itu, bahwa pendidikan karakter melatih pembiasaan (habituation) dalam perilaku yang baik. Dengan demikian, anak paham, mampu merasakan, dan otomatisasi untuk melakukan yang baik.

Pada intinya, misi utama pendidikan karakter adalah pendidikan moral. Pendidikan karakter adalah upaya yang dilakukan secara sengaja untuk dapat membantu peserta didik untuk mengerti, merawat serta berperilaku mulia (Frye, 2002). Dengan menanamkan karakter mulia sejak usia dini sangat menentukan perkembangkan potensi anak di masa mendatang. Melalui pendidikan karakter, anak dilatih dan dibiasakan agar mampu bertahan hidup dan menghindar dari perilaku yang tidak sesuai dengan nilai moral dan kebenaran. Anak akan memiliki kebijaksanaan untuk membedakan yang baik dan buruk sesuai kepatutan moral.

Penanaman nilai karakter pada anak sejak usia dini bukan sekedar tanggung jawab sekolah, melainkan kolaborasi dari tiga pihak yaitu lembaga sekolah, lembaga keluarga, dan masyarakat. Keluarga berperanan penting sebagai wadah utama dan pertama untuk menumbuhkembangkan karakter anak. Lembaga keluarga menjadi tumpuan membentuk karakter, bukan hanya anak, melainkan seluruh anggotanya, tetapi utamanya anak-anak yang masih dalam pengawasan, pembimbingan dan tanggung jawab orang tuan. Sekolah kebajikan pertama adanya dalam keluarga (Lickona, 2004). Dalam keluarga awal belajar tentang kasih sayang, komitmen, pengorbanan, dan keyakinan pada sesuatu yang lebih besar dari diri sendiri. Keluarga meletakkan dasar moral yang membangun semua lembaga sosial lainnya. Kegagalan untuk menanamkan nilai karakter pada anak, maka akan memicu terbentuknya pribadi yang bermasalah di masa dewasanya kelak.

Saat usia dinilah orangtua diharapkan berperan secara maksimal untuk mendidik dan menekankan nilai-nilai pendidikan karakter dengan menanamkan nilai-nilai kebaikan. Pendidikan karakter ini sangat penting bagi anak saat usia dini, karena di usia ini, anak lebih banyak menyerap dan menerima informasi secara cepat. Apa yang diberikan pada anak akan diserap dengan baik dan akan melekat lama dan akan menerapkan dalam kehidupannya.

Pendidikan karakter merupakan tanggung jawab sekolah. Menurut Sudaryanti (2012), sekolah adalah lembaga yang bertanggung jawab terhadap membentuk karakter anak, karena sekolah diberi kewenangan secara legal untuk mendidik. Kontribusi dan peran guru di sekolah sangat dominan. Tujuan pendidikan secara nasional adalah untuk membentuk insan yang memiliki intelektual, emosional, dan spiritual yang baik dan matang. 
Sekolah bertanggung jawab secara moral agar mendidik dan membentuk setiap anak menjadi pribadi yang cerdas dan sesuai dengan harapan orang tua dan masyarakat. Guru sebagai pendidik, memiliki peran penting untuk membentuk pribadi anak, karena tugas guru tidak hanya sekedar mentransfer ilmu. Guru harus hadir sebagai teladan dan pembentuk karakter. Keberadaan guru juga harus bisa memfasilitasi anak memperoleh pengetahuan yang bermanfaat bagi dirinya. Anak harus dituntun untuk memiliki karakter yang baik yang sesuai dengan tujuan pendidikan, yaitu mengembangkan potensi peserta didik untuk memiliki kecerdasan, kepribadian, dan akhlak mulia (Undang-Undang Sisdiknas tahun 2003 Pasal 1 ayat 1).

Pembentukan karakter (character building) anak dibentuk melalui implementasi pendidikan yang melibatkan seluruh aspek. Diantaranya adalah aspek pengetahuan (cognitif), aspek perasaan (feeling), dan aspek prilaku (action) (Sudaryanti, 2012). Guru profesional harus memahami dan mengetahui secara karakter siswanya. Untuk memahami karakter siswa beberapa hal yang dapat dilakukan, yaitu; mau menjadi pendengar yang baik, memahami kondisi emosional anak, mampu mengorek informasi terkait kehidupan anak.

Pengembangan karakter anak pada usia dini di sekolah dapat dikembangkan melalui beberapa kegiatan. Diantaranya adalah kegiatan rutin atau yang biasa disebut sebagai pembiasaan. Adapun kegiatannya adalah kegiatan terprogram, kegiatan spontan, dan keteladanan dari para pendidik. Pengertian pembentukan karakter dalam kegiatan terprogram merupakan kegiatan atau aktivitas yang sudah diagendakan atau dirancang sebelumnya. Program ini sudah termuat dalam kurikulum untuk jangka pendek ataupun jangka panjang. Misalnya untuk satu hari, satu minggu, satu bulan atau satu semester. Dalam kurikulum 2013, pendidikan karakter sudah terprogram dalam setiap mata pelajaran di sekolah.

Pembentukan karakter melalui kegiatan spontan adalah kejadian nyata yang terjadi dalam kehidupan sehari-hari di sekolah yang menuntut prilaku baik. Tujuannya adalah agar apresiasi anak terhadap nilai-nilai yang baik dapat meningkat dan muncul dari kehidupan nyata atau bukan karena dikondisikan. Pembentukan karakter melalui kegiatan keteladanan adalah memberi contoh dan keteladan yang ditunjukkan dari perilaku tenaga kependidikan. Anak bisa belajar dari contoh-contoh yang berkarakter baik dengan tujuan untuk mengarahkan anak belajar pola perilaku yang dapat diterima oleh masyarakat. Pembentukan karakter melalui kegiatan rutin atau pembiasaan bisa dilakukan seperti yang dipaparkan oleh Covey (2015) dengan menanamkan tujuh kebiasaan, yakni; proaktif, berpikir tentang tujuan akhir, dahulukan yang utama, berpikir untuk kemenangan bersama, memahami sebelum dipahami, bersinergi, dan mengasah kemampuan.

Pendidikan karakter juga menjadi tanggung jawab lingkungan atau masyarakat. Setiap norma yang ada di tengah masyarakat harus diikuti oleh seluruh warganya. Norma tersebut menjadi tolok ukur dan dasar untuk membentuk kepribadian, bertindak dan bersikap. Setiap norma merupakan aturan yang harus ditaati, ditularkan dan diregenerasikan oleh generasi tua kepada generasi berikutnya. Penanaman norma tersebut 
dilakukan secara sadar dengan tujuan agar generasi penerus dapat memahami dan menerapkannya. Hal ini merupakan proses dan peran pendidikan dalam masyarakat (Subianto, 2013).

Penanaman pendidikan moral (moral education) atau pendidikan karakter (character education), dalam konteks saat ini, sangat urgen untuk dilakukan. Hal ini terkait dengan krisis moral yang sedang melanda, diantaranya meningkatnya kebiasaan menyontek, pencurian, kejahatan terhadap teman, maraknya angka kekerasan anak dan remaja, perundungan, pergaulan bebas, penyalahgunaan obat-obatan, pornografi, dan perusakan lingkungan. Hal tersebut menjadi masalah sosial yang hingga saat ini belum dapat diatasi secara tuntas. Oleh karena itu, betapa urgensinya pendidikan karakter ditanamkan sejak usia dini di sekolah, masyarakat dan keluarga.

Berdasarkan paparan di atas, maka diharapkan pendidikan karakter dapat diimplementasikan secara konsiten, baik di keluarga, sekolah maupun masyarakat. Dengan demikian, pendidikan karakter berjalan secara linier (terintegrasi) antara sekolah, keluarga dan masyarakat dan berkesinambungan. Pendidikan yang terintegrasi akan mempermudah anak untuk memahami pendidikan karakter serta menerapkan dalam praktik kehidupan sehari-hari demi menjawab permasalahan yang dihadapi bangsa.

Menumbuhkembangkan pribadi yang berkarakter luhur dan bermoral harus dilakukan secara terus menerus atau berkelanjutan. Siswa yang dilatih dan dididik memiliki prilaku yang luhur akan menjawab dan mencapai cita-cita bangsa dan tujuan pendidikan nasional. Dalam penelitian ini, sekolah Katolik Santa Theresia Jakarta, sebagai lembaga pendidikan, merasa terpanggil dan bertanggung jawab untuk menanamkan pendidikan karakter sejak dini. Terutama yang berhubungan dengan visi misi dan nilai-nilai dari sekolah Santa Theresia Jakarta, yaitu servite et amate (layanilah dan cintailah). Anak tidak hanya dididik secara kognitif, tetapi dididik untuk memiliki karakter yang sesuai dengan nilai-nilai dan visi misi sekolah.

\section{b) Pendidikan Karakter untuk Anak Usia Dini}

Karakter yang harus dan penting untuk ditanamkan kepada anak menurut Zubaedi (2011) ada delapan belas nilai, yaitu; religius (keagamaan), disiplin, bertanggungjawab, mandiri, jujur, pekerja keras, memiliki rasa ingin tahu, toleransi, kreatif, demokratis, semangat kebangsaan, cinta tanah air, menghargai prestasi, bersahabat, komunikatif, cinta damai, gemar membaca, peduli lingkungan, dan peduli sosial. Sementara, menurut Subianto (2013), ada sembilan contoh kebiasaan yang dapat dilakukan untuk menanamkan nilai karakter di lingkungan keluarga melalui kegiatan pembiasaan yaitu, (1) Anak dilatih untuk bangun pagi sendiri, kemudian membereskan tempat tidur dan berolahraga; (2) Anak dilatih secara mandiri untuk mandi sendiri dan berpakaian sendiri; (3) Anak dilibatkan untuk ikut serta membantu menyelesaikan tugas-tugas rumah, misalnya bersih-bersih dan sebagainya; (4) Anak harus dilatih untuk mengatur dan memelihara barang kepunyaan sendiri; (5) Anak harus selalu dilatih jika hendak keluar rumah harus selalu pamit; (6) Anak harus selalu dilatih untuk mengucapkan salam, sesuai tradisi keluarga, saat keluar dan saat pulang ke rumah; (7) Melibatkan anak, sesuai kapasitasnya, untuk menerapkan musyawarah dan mufakat dalam keluarga, sehingga 
dalam diri anak akan tumbuh jiwa demokratis; (8) Anak harus dilatih untuk selalu bersikap sopan dan santun kepada orang tua maupun tamu; dan (9) Anak peduli terhadap orang lain dan lingkungan sekitar.

Lebih lanjut Subianto (2013) mengatakan bahwa ada beberapa contoh perilaku yang dapat diterapkan oleh masyarakat, seperti membiasakan anak untuk gotong royong, misalnya: membersihkan saluran air, menanami pekarangan rumah; membiasakan anak untuk tidak membuang sampah sembarangan dan merusak atau mencoret-coret fasilitas umum maupun rumah; orangtua harus selalu memberi masukan dan menegur anak yang tidak berperilaku baik.

\section{Pendidikan Karakter melalui Buku Cerita Bergambar}

Pendidikan karakter dengan memakai buku cerita bergambar diharapan mampu mengembangkan imajinasi anak serta menangkap pesan moral yang disampaikan melalui buku cerita tersebut. Buku cerita bergambar merupakan salah satu alternatif yang efektif untuk menanamkan nilai karakter kepada anak. Tujuan pendidikan karakter pada dasarnya, agar peserta didik bukan hanya orang yang terampil secara kognitif, tetapi juga menjadi orang yang bermartabat dan berkarakter yang baik. Orang yang berkarakter baik akan menjaga keutuhan diri yang meliputi keserasian, pikiran, perkataan dan perbuatan.

Buku cerita bergambar dengan penekanan nilai-nilai karakter yang disajikan bertujuan untuk membentuk anak menjadi pribadi yang baik. Mencapai tujuan pendidikan karakter tidak semudah membalikkan telapak tangan, melainkan proses penerapannya sejak dini dan secara terus menerus dilakukan. Dampak dari pendidikan karakter akan mempengaruhi prilaku anak hingga dewasa. Pengggunaan buku cerita bergambar ini, merupakan salah satu cara yang paling mudah untuk diterapkan dalam membentuk karakter anak, karena buku bergambar juga dapat mempengaruhi emosi anak.

Guru serta orangtua membutuhkan buku cerita bergambar untuk mengajar dan mendidik anak memiliki nilai-nila karakter. Buku cerita yang dirancang harus sesuai dengan perkembangan bahasa anak, cerita relevan dengan kehidupan sehari-hari, menarik, penuh warna, serta isinya harus sesuai dengan nilai-nilai karakter yang ingin ditanamkan.

\section{METODE PENELITIAN}

Metode penelitian yang diterapkan dalam penelitian ini adalah deskriptif. Metode deskriptif merupakan analisis data dari kumpulan data yang dihimpun untuk dideskripsikan sebagaimana adanya data tersebut tanpa harus membuat kesimpulan secara umum atau generalisasi (Sugiyono, 2012). Pengertian lainnya adalah upaya untuk menggambarkan atau mendeskripsikan fenomena yang terjadi dalam penelitian, atau suatu gejala, peristiwa, maupun kejadian yang sedang terjadi saat dilakukannya penelitian (Sudjana, 2004). Dengan demikian, dapat disimpulkan bahwa penelitian deskriptif adalah penelitian yang berusaha menggambarkan kejadian, bukan untuk mencari atau menguji teori, yang berlangsung pada saat penelitian dilaksanakan. Paparan data dalam penelitian ini tidak ada data kuantitatif atau berupa penyajian angka-angka statistik. Semua data dalam penelitian ini akan dipaparkan secara deskriptif atau naratif. Untuk memperoleh 
data, peneliti mengobservasi dan wawancara. Observasi dilakukan saat guru kelas mengajar serta mengamati buku-buku yang dipakai di Taman Kanak-kanak (TK) Santa Theresia Jakarta untuk pendidikan karakter. Informan dalam wawancara dilakukan kepada guru yang biasa mengajar pendidikan karakter di TK Santa Theresia Jakarta.

\section{HASIL DAN PEMBAHASAN \\ Buku Cerita Bergambar Dibutuhkan Untuk Pendidikan Karakter di TK Santa Theresia Jakarta}

Berdasarkan hasil wawancara kepada guru TK Santa Theresia Jakarta dan hasil observasi yang dilakukan. Dihimpun informasi, bahwa guru mengalami kesulitan mencari bahan ajar terkait dengan penanaman nilai-nilai karakter sesuai dengan visi dan misi sekolah. Hal ini, karena belum ada buku panduan dan atau buku cerita yang benarbenar memuat materi pendidikan karakter, khusus buat anak usia dini, sesuai visi misi sekolah. Buku cerita yang tersedia di sekolah tersebut hanya memuat pendidikan karakter secara umum. Tidak mengerucut pada visi dan misi yang diusung oleh sekolah. Padahal sekolah hendak membentuk karakter anak sejak dini sesuai nilai servite et amate (layanilah dan cintailah).

Buku cerita yang tersedia di sekolah hanya mencakup bagian kecil dari ke enam nilai yang ingin ditanamkan. Adapun enam nilai tersebut merupakan akronim dari servite et amate (layanilah dan cintailah), yaitu serviam, integrity, against the tide, compassionnate motherhood, achievement motivation, dan team spirit. Serviam artinya "saya mau mengabdi". Ini merupakan nilai dasar utama pendidikan ursulin yang dilandasi oleh semangat pemberian diri seutuhnya. Mengabdi yang dimaksud adalah kepada Allah, keluarga, masyarakat, Gereja, dan Negara. Integrity berarti integritas yang terwujud dalam diri para pendidik dan peserta didik yang berkepribadian holistis. Mengutamakan nilai-nilai kemanusiaan, kebenaran, kejujuran, dan keadilan. Orang yang berintegritas adalah orang-orang yang menghargai kehidupan dan keutuhan ciptaan serta keunikan pribadi sebagai citra Allah. Against the Tide berarti melawan arus dengan memiliki keberanian dan kepercayaan diri saat menghadapi "tawaran dunia" yang bertentangan dengan nilai-nilai dan norma-norma yang ada di masyarakat. Compasionnate Motherhood berarti semangat "keibuan" yang berbelas kasih. Para pendidik dan peserta didik diajak untuk mengembangkan sikap belas kasih, bela rasa, kelembutan hati, serta dapat memberikan peneguhan kepada yang lemah, takut dan mudah berkecil hati. Achievment Motivation artinya semangat berprestasi dan berinovasi. Semangat ini memotivasi setiap pendidik dan peserta didik untuk mengembangkan sikap mandiri, disiplin, tekun, kreatif, inovatif dan berdaya juang tinggi demi mencapai cita-cita luhur. Team Spirit artinya semangat bekerja sama dalam tim. Pendidik dan peserta didik membangun hidup dalam keserasian, sehati, sekehendak, terikat satu sama lain, kekeluargaan, persatuan dan solidaritas. 
Bahasa buku pendidikan karakter yang tersedia di sekolah TK Santa Theresia Jakarta juga kurang sederhana untuk tingkat anak TK. Kebanyakan buku cerita yang tersedia menggunakan bahasa yang sesuai untuk anak tingkat sekolah dasar (SD), sehingga saat dipakai buku tersebut, dampaknya anak kurang antusias dalam mengikuti pembelajaran. Hasil belajar anak juga kurang memuaskan dan anak tidak memahami contoh-contoh penerapan pendidikan karakter yang sesuai dengan nilai-nilai yang ingin ditanamkan oleh sekolah.

Saat dilakukan wawancara kepada guru dengan mengajukan pertanyaan: "Menurut Anda, sumber belajar seperti apa yang dibutuhkan untuk dikembangkan khususnya terkait pada penanaman nilai-nilai karakter sekolah?" Jawaban atas pertanyaan tersebut adalah semua guru mengutarakan bahwa buku cerita bergambar yang mencakup nilai-nilai karakter yang sesuai dengan visi misi sekolah sangat dibutuhkan. Buku cerita yang dibutuhkan menurut pendapat guru adalah buku berukuran minimal A4, penuh warna (full color), menggunakan bahasa yang cocok untuk anak TK, dan materi cerita sebaiknya diambil dari kehidupan sehari-hari. Dengan demikian pembelajaran pendidikan karakter akan mudah diserap anak secara maksimal dan isi cerita bisa dipahami dengan baik.

Jika paparan di atas dikaitkan dengan teori yang dijelaskan oleh Anitah (dalam Sari, 2010), bahwa karakteristik cerita bergambar yang baik adalah gambar dan isi cerita cocok dengan tingkatan umur maupun kemampuan anak, isi cerita maupun gambar tidak rumit atau kompleks, gambar yang dibuat realistis atau mirip seperti benda yang sesungguhnya, dan gambar harus dapat diraba dan dipegang oleh anak didik.

\section{Peran Buku Cerita Bergambar}

Menurut guru berdasarkan hasil wawancara dengan mengajukan pertanyaan "Menurut Anda apa peran buku cerita bergambar dalam pembelajaran?". Jawaban guru dapat disimpulkan sebagai berikut; bahwa dengan adanya buku cerita bergambar, anak lebih mudah memahami contoh penerapan nilai-nilai karakter yang terkandung dalam buku cerita tersebut. Apa lagi jika isi cerita memuat kisah nyata atau cerita yang dikaitkan dengan kehidupan sehari-hari. Menurut guru, dengan adanya buku cerita bergambar tersebut dapat menolong anak untuk memahami cara penerapan nilai-nilai karakter secara nyata dalam kehidupan sehari-hari.

Paparan di atas sesuai dengan teori bahwa buku cerita bergambar bermanfaat sebagai sarana pembelajaran maupun sebagai sumber belajar yang mudah ditemukan. Di sisi lain, buku cerita bergambar menurut Susanto (2011) ada tiga manfaatnya, yaitu (1) membantu untuk menambah kosa kata baru bagi anak, (2) memberikan visualisasi cerita yang mudah dipahami anak lewat gambar, dan (3) memberi stimulus verbal dan imajinasi anak berkembang lewat visualisasi gambar.

Oleh karena itu, dengan adanya masukan dari guru-guru dan hasil observasi, seperti yang sudah dipaparkan di atas dan berdasarkan analisis kebutuhan, maka sangat perlu untuk dikembangkan buku cerita bergambar dengan ide, alur, latar, tema, dan tokoh cerita yang sesuai dengan kebutuhan belajar di TK Santa Theresia Jakarta. Intinya buku cerita bergambar sangat urgen untuk dikembangkan di TK Santa Theresia Jakarta dengan 
muatan materi yang menekankan nilai-nilai karakter yang sesuai dengan visi misi sekolah, yaitu servite et amate (layanilah dan cintailah).

\section{SIMPULAN}

Pendidikan karakter dengan menggunakan buku cerita bergambar di TK Santa Theresia Jakarta Pendidikan sangat urgen, karena di sekolah tersebut, belum tersedia buku cerita bergambar yang isi ceritanya sesuai dengan servite et amate (layanilah dan cintailah). Kehadiran buku cerita bergambar bermanfaat untuk dapat membantu anakanak untuk memahami isi cerita bacaan dan mempermudah mengimplementasikan nilai karakter dalam kehidupan nyata. Buku cerita bergambar juga mampu melibatkan kognitif, emosi dan imajinasi anak, karena buku tersebut harus dirancang dengan penuh warna, ide, alur, latar dan isi cerita yang diambil dalam kehidupan nyata. Dengan demikian, anak akan mudah memahami isi konsep cerita dengan penekanan nilai-nilai karakter. Buku cerita bergambar yang dikembangkan harus sesuai dengan nilai visi misi sekolah Santa Theresia Jakarta. Oleh karena dirasakan perlu oleh guru TK, maka harus dikembangkan buku cerita bergambar dengan penekanan pada nilai-nilai servite et amate untuk digunakan sebagai sumber pembelajaran.

Berdasarkan hasil penelitian ini, bahwa sangat dibutuhkan pengembangan buku cerita bergambar dengan penekanan pada nilai-nilai servite et amate untuk pendidikan karakter anak usia dini. Ada beberapa hal yang bisa disarankan terkait pengembangan buku cerita bergambar tersebut, yaitu; (1) berdasarkan analisi kebutuhan yang disampaikan oleh guru-guru, maka sekolah perlu memfasilitasi dan mendukung penuh, agar guru TK diberikan ruang dan kesempatan untuk mengembangkan buku cerita bergambar. (2) Alur, tokoh dan isi cerita yang disusun dengan penekanan pada nilai karakter servite et amate harus relevan bagi anak usia dini. (3) Penggunaan bahasa dan pemilihan diksi dalam cerita bergambar harus sesuai dengan pertumbuhan kognitif anak usia dini. Saat mengembangkan buku cerita bergambar, pengembang harus memperhatikan komposisi warna agar menarik dan ilustrasi mendorong imajinasi anak.

\section{DAFTAR PUSTAKA}

Adipta, H., Maryaeni, M., \& Hasanah, M. (2016). Pemanfaatan Buku Cerita Bergambar Sebagai Sumber Bacaan Siswa Sd. Jurnal Pendidikan: Teori, Penelitian, dan Pengembangan, 1(5), 989-992. doi:http://dx.doi.org/10.17977/jp.v1i5.6337

Berk, L. E. (2012). Development trough the lifespan. Yogyakarta: Pustaka Pelajar.

Covey, S. (2015). The 7 habits of highly effective people. Miami: Free Press.

Faizah, U. (2009). Keefektifan cerita bergambar untuk pendidikan nilai dan keterampilan berbahasa dalam pembelajaran bahasa Indonesia. Jurnal Cakrawala Pendidikan, 27(3), 249-256. (Online). (https://journal.uny.ac.id/index.php/cp/article/view/302/pdf, diakses, 17 April 2019) 
Frye, et al. (2002). Character education: informational handbook and guide for support and implementation of the student citizent act". North Carolina: Public Schools of North Carolina.

Hartati, S. (2005). Perkembangan belajar pada anak. Jakarta: Depdiknas.

Kosasih, E. (2009). Mantap bersastra Indonesia. Bandung: Yrama Widya.

Koesoema A, D. (2007). Pendidikan karakter. Jakarta: Grasindo

Kementrian Pendidikan Nasional Badan Penelitian Pengembangan Pusat Kurikulum Badan Pelatihan. (2010). Pengembangan pendidikan budaya dan karakter bangsa. Jakarta: Kementrian Pendidikan Nasional.

Lickona. (2004). Character matters. How to help our children develop good judgment, integrity, and other essential virtues. Sydney

Mitchell, D. (2003). Children's literature an imitation to the word. Michigan State University.

Mueller, S. (2006). Panduan belajar membaca dengan benda-benda di sekitar untuk usia 3-8 tahun. Jakarta: Erlangga.

Nodelman, P. (2008). The hidden adult: Defining children's literature. Baltimore: John Hopkins University Press.

Nur, H. (2013). Membangun karakter anak melalui permainan anak tradisional. Jurnal Pendidikan Karakter, 3(1), 87-94. (Online). (https://journal.uny.ac.id/index.php/jpka/article/view/1290/1074, diakses, 17 April 2019)

Nurgiyantoro, B. (2013). Sastra anak pengantar pengalaman dunia anak. Yogyakarta: Gajah Mada University Press.

Prasanti dan Fitriani. (2018). Pembentukan karakter anak usia dini: Keluarga, Sekolah, Dan Komunitas? (Studi Kualitatif tentang Pembentukan Karakter Anak Usia Dini Melalui Keluarga, Sekolah, dan Komunitas. (Online). (https://obsesi.or.id/index.php/obsesi/article/view/2/2, diakses, 13 April 2019)

Republik Indonesia. (2003). Undang-Undang Republik Indonesia Nomor 20 Tahun 2003 tentang Sistem Pendidikan Nasional Pasal 1 ayat 1.

Rideout, V. J., Vandewater, E. A., \& Wartella, E. A. (2003). Zero to six: Electronic media in the lives of infants, toddlers, and preschoolers. (Online). (http://www.kff.org/entmedia/3378.cfm,_diakses, 13 April 2019)

Rothlein, L., Meinbach, A. M. (1995). Literature Connection Using Children's Book in the Classroom. London: Foresman and Company.

Sari, A. K. (2010). Pengaruh penggunaan media cerita bergambar terhadap peningkatan ketrampilan menyimak dan membaca pada anak berkesulitan belajar kelas II SDN Peterongan Jebres Surakarta tahun ajaran 2009/2010. (Online). (https://eprints.uns.ac.id/3404/1/173522312201007441.pdf, diakses, 17 April 2019).

Soelistyarini, T. D. (2011). Cerita anak dan pembentukan karakter. Disampaikan dalam Lokakarya Pembentukan Karakter Bangsa Melalui Sastra Anak. Surabaya: 
Universitas

Airlangga.

(Online).

(https://www.academia.edu/7304333/Cerita_Anak_dan_Pembentukan_Karakter?a uto=download, diakses, 17 April 2019)

Subianto, J. (2013). Peran Keluarga, Sekolah, dan Masyarakat dalam Pembentukan Karakter Berkualitas. Edukasi: Jurnal Penelitian Pendidikan Islam, 8(2), 331-354. (Online). (http://journal.stainkudus.ac.id/index.php/Edukasia/article/view/757/726, diakses, 17 April 2019)

Sudaryanti. (2012). Pentingnya pendidikan karakter bagi anak usia dini. Jurnal Pendidikan Anak, 1(1), 11-20. (https://journal.uny.ac.id/index.php/jpa/article/view/2902/2416, diakses, 17 April 2019)

Sudjana, N. (2004). Dasar-dasar proses belajar mengajar. Bandung: Sinar Baru Algensido Offset.

Sugiyono. (2012). Memahami penelitian kualitatif. Bandung: CV. Wacana Prima.

Soehendro, P. (2011). Bercerita pada anak. Jakarta: Direktorat Pembinaan Pendidikan Anak Usia Dini Direktorat Jenderal Pendidikan Anak Usia Dini Nonformal dan Informal Kementerian Pendidikan Nasional. (Online). (http://paud.kemdikbud.go.id/wp-content/uploads/2016/04/bercerita-pada-anakfile.pdf, diakses, 17 April 2019)

Susanto, A. (2011). Perkembangan anak usia dini. Jakarta: Kencana Prenada. Media Group.

Suyanto, S. (2005). Konsep dasar anak usia dini. Jakarta: Departemen Pendidikan Nasional.

Turan, F., \& Ulutas, I. (2016). Using story books as a character educational tools. Journal of Education and Practice. 7(15), 169-176. Online. (https://eric.ed.gov/?id=EJ1103139, diakses, 16 Januari 2019).

Zubaedi. (2011). Desain pendidikan karakter: konsepsi dan aplikasinya dalam lembaga pendidikan. Jakarta: Kencana. 